\title{
Real-time evaluation of individual cow milk for higher cheese-milk quality with increased cheese yield
}

\author{
G. Katz, ${ }^{*}$ U. Merin, ${ }^{*}$ D. Bezman, ${ }^{*}$ S. Lavie, ${ }^{*}$ L. Lemberskiy-Kuzin, ${ }^{*}$ and G. Leitner ${ }^{1}$ \\ *Afimilk, Afikim 15148, Israel \\ †National Mastitis Reference Center, Kimron Veterinary Institute, PO Box 12, Bet Dagan 50250, Israel
}

\begin{abstract}
Cheese was produced in a series of experiments from milk separated in real time during milking by using the Afilab MCS milk classification service (Afikim, Israel), which is installed on the milk line in every stall and sorts milk in real time into 2 target tanks: the A tank for cheese production $(\mathrm{CM})$ and the $\mathrm{B}$ tank for fluid milk products (FM). The cheese milk was prepared in varying ratios ranging from $\sim 10: 90$ to $\sim 90: 10$ CM:FM by using this system. Cheese was made with corrected protein-to-fat ratio and without it, as well as from milk stored at $4^{\circ} \mathrm{C}$ for $1,2,3,4$, and $8 \mathrm{~d}$ before production. Cheese weight at $24 \mathrm{~h}$ increased along the separation cutoff level with no difference in moisture, and dry matter increased. The data compiled allowed a theoretical calculation of cheese yield and comparing it to the original van Slyke equation. Whenever the value of Afi-Cf, which is the optical measure of curd firmness obtained by the Afilab instrument, was used, a better predicted level of cheese yield was obtained. In addition, 27 bulk milk tanks with milk separated at a 50:50 CM:FM ratio resulted in cheese with a significantly higher fat and protein, dry matter, and weight at $24 \mathrm{~h}$. Moreover, solids incorporated from the milk into the cheese were significantly higher in cheeses made of milk from A tanks. The influence of storage of milk up to $8 \mathrm{~d}$ before cheese making was tested. Gross milk composition did not change and no differences were found in cheese moisture, but dry matter and protein incorporated in the cheese dropped significantly along the storage time. These findings confirm that milk stored for several days before processing is prone to physico-chemical deterioration processes, which result in loss of milk constituents to the whey and therefore reduced product yield. The study demonstrates that introducing the unknown parameters for calculating the predicted cheese yield, such as the empiric measured
\end{abstract}

Received November 5, 2015.

Accepted February 16, 2016.

${ }^{1}$ Corresponding author: leitnerg@moag.gov.il
Afi-Cf properties, are more accurate and the increase in cheese yield is more than increasing just the protein level, the value that is being tested by the dairies, or even casein.

Key words: real-time milk sorting, cheese-milk quality, cheese yield

\section{INTRODUCTION}

Over the years, the term "milk quality" has been used in its general sense, and several standard manuals and textbooks are available on milk quality control. In the recent edition of the Dairy Encyclopedia, Kelly et al. (2011) used a more general approach, stating that, "The quality of milk may be evaluated by measuring the parameters that indicate both its suitability for consumption or processing into dairy products and the health status of the cow or herd producing the milk." However, searching for the term "milk quality" results mostly in programs to reduce SCC and lower bacteria counts in the bulk milk tank. Moreover, milk quality is usually bound to safety, making use of a new term, "milk safety," which is actually used as a synonymous term to "milk quality" (Leitner et al., 2015).

On farm, bulk milk composition is the sum of the milk contributed by all the animals milked into it, and it depends on breed, nutrition, and time in lactation as well as udder infection of the individuals in the herd. Nonetheless, high-quality milk composition and properties for drinking milk are stricter than that of milk intended for manufacturing of cheese or yogurt. For that, different animals and different breeds may be selected and diverse products have been developed according to standard desirable dairy products (Wedholm et al., 2006; De Marchi et al., 2008). Consequently, high fat or protein can be related to higher cheese yield and therefore important in the term high-quality milk for cheese making, whereas for drinking milk, a high fat level may not be preferred and a high protein level may be associated with economic loss to the milk producer. Similarly, time in lactation, low milk solids at the early stages and high solids at the end of the lactation period can result in different products (Palmquist et al., 1993; 
Auldist et al., 1996; Auldist and Hubble, 1998; Tufarelli et al., 2009). Thus, increased milk quality derived from increased milk safety could partially be achieved by withholding milk of infected glands from the bulk milk tank and could enable the industry to focus on new quality parameters.

The cheese industry depends on milk quality for achieving a high yield and reputability in texture and taste. Properties of milk quality for cheese making were discussed long ago by van Slyke (1907) and later on by van Slyke and Price (1941). The incentive to predict the yield of cheese from a given volume of milk was first documented by S. M. Babcock in 1895 (Emmons and Modler, 2010). All the predictive yield formulas deal with milk composition (or formulation) and its influence when producing cheeses of various compositions. Although the prediction was not totally accurate, the perception of milk quality was in line as it was related to milk composition and quality of the cheese, moisture, and constituent levels (Bangstra et al., 1988; Aleandri et al., 1989; Guinee et al., 2006).

During the last $5 \mathrm{yr}$, Afimilk (Afikim, Israel) introduced the AfiMilk MCS (online milk classification service), which is installed on the milk line in every stall and sorts milk in real time according to its optical measured coagulation properties: Afi-Cf (Leitner et al., 2011a, 2012). In addition, the system measures milk constituents: fat, protein, and lactose. Milk flows through 2 parallel milk lines according to Afi-Cf into target bulk milk A tank or B tank, resulting in milk suitable for desired dairy products. Bulk A tank is assigned for cheese manufacturing and contains $\sim 7 \%$ higher protein and $\sim 15 \%$ higher fat compared with the herd's basal milk levels, which increases cheese vat production yield by up to $15 \%$, whereas B tank is suited for fermented and other fluid milk products (Leitner et al., 2011a, 2012, 2013). The volume of milk designated for cheese manufacturing is determined by pre-setting the Afi-Cf cutoff level at the milking parlor according to the level desired by the dairy plant. The unique method relies on optical observation only and milk channeling; it does not manipulate, modify, heat, or add any ingredients to the milk (Leitner et al., 2011a, 2012, 2013).

The objective was to evaluate raw milk value for a final product as the basis for its price. In the process of calibrating the AfiMilk MCS system, it was found that in comparison with van Slyke's equation, $\sim 4 \%$ of the increased cheese yield was not explained by the equation. Because the increase in cheese yield was not fully related to the increase in milk constituents, further experiments were conducted to assess the contribution of the optical analysis and channeling milk with different composition to the increased yield of the cheese vats produced from designated cheese milk. In addition, van Slyke's equation was tested with stored milk, where fat, protein, and casein remained constant, to assess the effect of raw milk storage time on cheese yield.

\section{MATERIALS AND METHODS}

\section{Animals, Milk Sampling, and Preparation for Cheese Making}

The milk originated from 4 arbitrarily chosen commercial dairy farms (350-450 Israeli-Holstein cows/ farm). The farm's milking parlors were equipped with the AfiLab MCS system, composed of 2 parallel milk lines and 2 target bulk milk tanks: $\mathrm{A}$ and $\mathrm{B}$, which allowed a predefined separation of different ratios of milk into each target tank, A or B tank.

\section{On-Farm Milk Separation}

Milk was separated into the 2 target tanks, A and B, where the A tank was assigned for cheese production $(\mathbf{C M})$ and the B tank for fluid milk products (FM). The series of separation ratios ranged from $\sim 10: 90$ to 90:10 CM:FM and 2 extra bulk milk tanks represented unseparated milk that served as control. All bulk milk samples were of a whole day collection ( $\times 3$ milking). From each separation, $5 \mathrm{~L}$ of milk was sampled from the bulk milk tank and transferred to the laboratory in $1 \mathrm{~h}$ at $4^{\circ} \mathrm{C}$. The milk was gently mixed and $40 \mathrm{~mL}$ was preserved with Bronopol (Broad Spectrum Microtabs II, D\&F Control Systems Inc., San Ramon, CA) for gross milk composition testing. Protein, casein, fat, lactose, and urea contents were analyzed with the Milkoscan 6000 (Foss Electric, Hillerød, Denmark) and SCC with a Fossomatic 360 (Foss Electric). For cheese making, each milk sample of A tank and B tank was standardized for protein-to-fat ratio (PTF). Protein content of each separation at the farm was based on the protein level recorded by the Afilabs. Fat content was tested for each sample by Gerber butyrometer (Gerber Instruments AG, Effretikon, Switzerland) and 1 L milk was skimmed by centrifugation and added to achieve a PTF ratio of 1:0.95. After milk standardization, 40 $\mathrm{mL}$ was preserved with Bronopol for cheese-milk gross composition analysis. Cheese was made in 4 repetitions. Unpreserved milk $(10 \mathrm{~mL})$ was used for measuring rennet clotting time (min) and curd firmness (Cf; V) after 60 min (CF-60) using the Optigraph (Ysebaert, Frepillon, France) as described by Leitner et al. (2011b).

Milk samples of 27 AfiLab MCS bulk A and B tanks in the ratio of 50:50 CM:FM were collected, the milk was tested for composition, and cheese was made without correcting the PTF ratio. 


\section{Storage of Milk Before Cheese Making}

Bulk milk samples (100 L) of a single day collection $(\times 3$ milking) to ensure a representative sample of the farm's milk composition were used. The milk was allocated to $10-\mathrm{L}$ containers after gentle mixing at $30^{\circ} \mathrm{C}$. The containers were stored at $4^{\circ} \mathrm{C}$ up to $8 \mathrm{~d}$. Daily, starting on $\mathrm{d} 1,2,3,4$, and 8 , one of the containers was heated to $30^{\circ} \mathrm{C}$, gently mixed, and cheese was made in duplicates with and without added $\mathrm{CaCl}_{2}$.

\section{Cheese Making}

For cheese making, six 1-L stainless steel containers were placed in a thermostatically controlled water bath. The milk was preheated for $25 \mathrm{~min}$ at $30^{\circ} \mathrm{C}$. A solution of $61.76 \mathrm{~g} / \mathrm{L}$ of $\mathrm{CaCl}_{2}$ was added after 10 min heating to achieve a final $\mathrm{CaCl}_{2}$ concentration of 0.00 to 0.2038 g/L. Maxiren 600 (DSM Food Specialties B.V., Delft, the Netherlands) at $0.089 \mathrm{~g} / \mathrm{L}$ was added to each container and incubated for $60 \mathrm{~min}$ till cutting into $0.8-\mathrm{cm}$ cubes by stainless steel knives. The cut curd was left to stabilize for $10 \mathrm{~min}$, and then the temperature was raised to $40^{\circ} \mathrm{C}$ and cooked for additional 25 min with gentle stirring. The curd was poured into perforated molds and turned over after $10 \mathrm{~min}$. The cheese stored pressed at $46 \mathrm{~g} / \mathrm{cm}^{2}$ for $24 \mathrm{~h}$ at $4^{\circ} \mathrm{C}$. Whey was collected and weighed for yield calculation. Dry matter in cheese was determined according to standard methods (Marshall, 1992).

Whey optical reflectance was measured using Ocean optics USB2000 spectrometer (Instruments NE, Westfield, MA).

\section{Raw Milk Cheese Yield Theoretical Calculation: Beyond van Slyke's Equation}

For over 100 yr, van Slyke's theoretical equation is used as a propensity for predicting cheese yield from a liter of milk:

$$
\frac{\mathrm{kg}}{\mathrm{L}}(\text { fat, } \operatorname{prot})=\frac{(\alpha \text { fat }+\sigma \text { prot })}{\mathrm{M}},
$$

where prot $=$ protein, $\alpha$ and $\sigma=$ constants, and $\mathrm{M}$ $=$ moisture. The equation considers expected constant loss of solids from the initial quantity to predict yield. An assumption that this loss can be attributed to the imperfection of the processing procedure can only be partially right. Protein and fat are not the only factors that determine the potential of raw milk coagulation and its incorporation in the curd matrix. Other unknown factors contribute to the coagulation potential (milk acidity, calcium addition as well as 60 different organic metabolites, different casein type distribution, proteolysis, and so on; Fox and Cogan, 2004; Boudonck et al., 2009; Bittante et al., 2012). Time to processing has an effect on cheese yield, whereas no loss of solids can be recorded. Therefore, a more complete theory for cheese yield prediction equations should include these unknowns, some of which are time dependent.

A naive way to approximate the effect of all the unknown components in milk on cheese yield is to assume they have linear effects (time dependent or not), so a new equation conserving van Slyke's equation structure will look like

$$
\begin{aligned}
& \frac{\mathrm{kg}}{\mathrm{L}}(\text { fat, prot, } \varphi(t), \sigma(t), \theta, ?)= \\
& \frac{(\alpha \text { fat }+\sigma \operatorname{prot}+\varepsilon t+\varphi x+\sigma y+\theta z, ?+?)}{\mathrm{M}},
\end{aligned}
$$

where $x, y$, and $z$ represent additional milk components and $\varphi, \sigma$, and $\theta$ are constants. Because we do not have all the relevant unknowns $(\varphi, \sigma, \theta, ?)$, we can replace them with an empiric measurable property that represents the effect of all factors composing the milk's coagulation potential. Such a property is the empiric measured Afi-Cf milk clotting parameter (MCP): AfiCf MCP. This parameter is derived from the known milk clotting parameters $\mathrm{Cf}$ and rennet clotting time measured by the Optigraph. In an effort to predict yield for a variety of cheese types with a single observation of the raw milk parameters on the farm level, the new equation includes fat, protein, and moisture as well as Afi-Cf, which was standardized without using additives (Equation [3]).

Better understanding of the nature of $\mathrm{MCP}$ can be achieved by comparing the weight of each property of the milk in the equation and in similar equations excluding some of the properties (Equations [4], [5], [6]):

$$
\begin{aligned}
& \frac{\mathrm{kg} \text { of cheese }}{100 \mathrm{~L}}(\text { fat, prot, } \mathrm{MCP})= \\
& \frac{\alpha \times \text { fat }+\beta \times \operatorname{prot}+\gamma \times \text { Afi-Cf }}{\mathrm{M}},
\end{aligned}
$$

$$
\begin{aligned}
\frac{\mathrm{kg} \text { of cheese }}{100 \mathrm{~L}}(\mathrm{fat}, \mathrm{MCP}) & =\frac{\beta^{\prime} \times \mathrm{fat}+\gamma^{\prime} \times \text { Afi-Cf }}{\mathrm{M}},[4] \\
\frac{\mathrm{kg} \text { of cheese }}{100 \mathrm{~L}}(\text { prot}, \mathrm{MCP}) & =\frac{\beta^{\prime} \times \text { prot }+\gamma^{\prime} \times \text { Afi-Cf }}{\mathrm{M}}, \\
\frac{\mathrm{kg} \text { of cheese }}{100 \mathrm{~L}}(\mathrm{MCP}) & =\frac{\gamma^{\prime \prime} \times \text { Afi-Cf }}{\mathrm{M}}+\frac{\mu}{\mathrm{M}^{2}},
\end{aligned}
$$


where $\alpha, \beta, \beta^{\prime}, \gamma, \gamma^{\prime}$, and $\gamma^{\prime \prime}$ are the constants for each of the parameters measured. These 4 new equations are within the structure of van Slyke's approximation and do not address time dependence on MCP.

\section{Statistical Analyses}

The effect of milk separation $(\mathrm{n}=27)$ on milk components, $\mathrm{SCC}$, fat/protein ratio, $\mathrm{CF}-60$, cheese weight at $24 \mathrm{~h}$, moisture, and percent DM was analyzed using SAS GLM procedure (data are presented as means and SEM). The main effect was the bulk tank milk. Probability values of $\leq 0.05$ were considered significant. Correlations between parameters were tested using the SAS PROC CORR procedure (version 9.2, 2009; SAS Institute Inc., Cary, NC). Regression analysis was performed using Excel (Microsoft Corp., Redmond, WA).

\section{RESULTS}

\section{On-Farm Milk Separation and Cheese Making}

Milk gross composition according to test number and bulk A or B tank separation cutoff level ratios from $\sim 10: 90$ to $90: 10$ as assigned for cheese manufacturing/ fluid milk products are presented in Table 1. No significant differences were found between bulk A and B tanks in SCC and lactose. In contrast, significant differences $(P<0.05)$ were noted in fat, protein, and casein. The ratio of casein to protein was always higher in the A tank regardless of the separation cutoff level. Figure 1A illustrates the increase of casein, whereas Figure 1B shows the increase of protein/casein (\% casein) in relation to the separation levels that entered bulk $\mathrm{A}$ and $\mathrm{B}$ tanks and the 2 controls of unseparated milk. The increase in casein was higher than that of total protein, which resulted in higher $\%$ casein.
After fat equilibration, PTF values ranged between 0.91 and 0.98 (Table 2). The CF-60 and cheese weight at $24 \mathrm{~h}$ increased along with the separation cutoff level (Table 2 and Figure 2). The correlation between the 2 parameters was 0.803 . No differences were found in the moisture of the cheeses at $24 \mathrm{~h}$. However, DM increased along with the separation cutoff level (Table 2 and Figure 3), thus, resulting in higher casein levels in the cheese.

The data compiled during the experiments allowed a theoretical calculation of milk components in cheese making. Each of Equations [7]-[10] was compared with the original van Slyke equation and its graphics are presented in Figure 4. Whenever the value Afi-Cf was used, a better predicted value of cheese yield was obtained, compared with van Slyke's calculated yield. $\mathrm{R}^{2}$ : van Slyke $=0.83 ; \mathrm{f}$ (prot, fat, Afi-Cf, w) $=0.980 ; \mathrm{f}$ (fat, Afi-Cf, w) $=0.975$; f (prot, Afi-Cf, w) $=0.945$; and for $\mathrm{f}($ Afi-Cf, $w)=0.876$. The coefficient of the fat is larger than in van Slyke, whereas the protein coefficient is smaller. The normalized effect of Afi-Cf on cheese yield was $\sim 17 \%$ for Equations [7] and [9], 11\% for Equation [8], and $70 \%$ for Equation [10]. Equation [8] results in better prediction than Equation [9] (Leitner et al., 2013) because fat is required as complementary data to protein and protein efficiency. At the asymptotes, the predictions of van Slyke's equations are not linear but of higher order:

$$
\begin{gathered}
\frac{\mathrm{kg} \text { of cheese }}{100 \mathrm{~L}}(\text { fat, prot, MCP })= \\
\frac{1.33 \times \text { fat }+0.492 \times \operatorname{prot}+0.099 \times \text { Afi-Cf }}{\mathrm{M}}, \\
\frac{\mathrm{kg} \text { of cheese }}{100 \mathrm{~L}}(\text { fat }, \mathrm{MCP})=\frac{1.86 \times \text { fat }+0.065 \times \text { Afi-Cf }}{\mathrm{M}},
\end{gathered}
$$

\begin{tabular}{|c|c|c|c|c|c|c|c|c|}
\hline Test & $\begin{array}{l}\text { Target } \\
\text { tank }\end{array}$ & $\begin{array}{l}\text { Separation } \\
\text { ratio }\end{array}$ & Fat $(\mathrm{g} / \mathrm{L})$ & $\begin{array}{l}\text { Protein } \\
(\mathrm{g} / \mathrm{L})\end{array}$ & $\begin{array}{c}\text { Casein } \\
(\mathrm{g} / \mathrm{L})\end{array}$ & $\begin{array}{c}\% \\
\text { Casein }\end{array}$ & $\begin{array}{l}\text { Lactose } \\
(\mathrm{g} / \mathrm{L})\end{array}$ & $\begin{array}{c}\text { SCC } \\
\left(\times 10^{3}\right)\end{array}$ \\
\hline \multirow[t]{2}{*}{1} & A & 9.4 & 60.1 & 38.3 & 29.4 & 76.7 & 48.8 & 208 \\
\hline & B & 90.6 & 37.8 & 32.6 & 24.7 & 75.7 & 50.1 & 205 \\
\hline 2 & B & 80.0 & 36.1 & 32.2 & 24.4 & 75.7 & 50.0 & 265 \\
\hline \multirow[t]{2}{*}{3} & $\mathrm{~A}$ & 48.6 & 47.9 & 34.3 & 26.2 & 76.3 & 49.8 & 266 \\
\hline & B & 51.4 & 30.4 & 31.5 & 23.7 & 75.2 & 50.2 & 230 \\
\hline \multirow[t]{2}{*}{5} & $\mathrm{~A}$ & 87.0 & 42.1 & 33.1 & 25.2 & 76.1 & 50.1 & 222 \\
\hline & B & 13.0 & 29.0 & 31.5 & 23.6 & 75.0 & 49.6 & 242 \\
\hline Unseparated control 1 & & & 38.9 & 33.0 & 24.9 & 75.6 & 50.1 & 238 \\
\hline Unseparated control 2 & & & 40.5 & 33.0 & 25.0 & 75.8 & 50.1 & 210 \\
\hline
\end{tabular}

Table 1. Raw milk composition (fat, protein, casein, and lactose), percent casein of protein (\% casein), and SCC in target A and B tanks according to separation threshold using the AfiMilk MCS system and 2 controls of unseparated milk 


$$
\begin{gathered}
\frac{\mathrm{kg} \text { of cheese }}{100 \mathrm{~L}}(\text { prot, } \mathrm{MCP})= \\
\frac{1.72 \times \text { prot }+0.0196 \times \text { Afi-Cf }}{\mathrm{M}}, \\
\frac{\mathrm{kg} \text { of cheese }}{100 \mathrm{~L}}(\mathrm{MCP})=\frac{0.94 \times \text { Afi-Cf }}{\mathrm{M}}+\frac{2.14}{\mathrm{M}^{2}} .
\end{gathered}
$$

The coefficients for the equations were acquired using linear regression. Validation was performed employing the leave-one-out cross-validation linear regression process (Shao, 1993; Kohavi, 1995; Leitner et al., 2011a).

\section{Milk Separation at 50:50 Ratio for A and B Tanks and Cheese Making}

Overall, 27 milkings (each of 3 milkings/day) were separated at a ratio of 50:50 into tanks $\mathrm{A}$ and $\mathrm{B}$ and were tested for cheese making: 13 from the A tank and 14 from the B tank. No significant differences were found in lactose and SCC levels between the milk in the $\mathrm{A}$ and $\mathrm{B}$ tanks (Table 3). Fat, protein, PTF, and CF-60 were significantly higher in A tanks than in B tanks. Correlation between CF-60 and fat was $\mathrm{R}^{2}=$ $0.911(P<0.0001)$ and between $\mathrm{CF}$ and protein was $\mathrm{R}^{2}=0.817(P<0.0001)$. Cheese weight at $24 \mathrm{~h}$ and percent DM were significantly higher in cheese made of milk from A tanks than B tanks (Table 3). The correlation between cheese weight at $24 \mathrm{~h}$ and fat $\left(\mathrm{R}^{2}=0.927\right.$; $P<0.0001)$ and protein $\left(\mathrm{R}^{2}=0.835 ; P<0.0001\right)$ was similar to DM. Moreover, a significant positive correlation was also found with CF-60 $\left(\mathrm{R}^{2}=0.920 ; P<\right.$ 0.0001). Percent moisture in cheese made of milk from A tanks was significantly higher than that in B tanks. Thus, to test the TS in the milk incorporated into the cheese, the contents of fat and protein in the milk and in DM were used. Because no evaluation of the cheese composition was made, it was assumed that ash and noncasein matter are at a fixed level of $4 \mathrm{~g} / \mathrm{L}$ in all the cheese samples, and this value was subtracted from the cheese produced for further calculations. The results clearly indicated that the solids incorporated from the milk into the cheese were significantly higher in cheeses made of milk from A tanks (Figure 5). Moreover, it also indicates that PTF separated by the AfiMilk MCS did not result in higher loss of fat to the whey.

\section{Storage of Milk Before Cheese Making}

During the $8 \mathrm{~d}$ of storage of the milk before cheese making, gross milk composition did not change: (fat
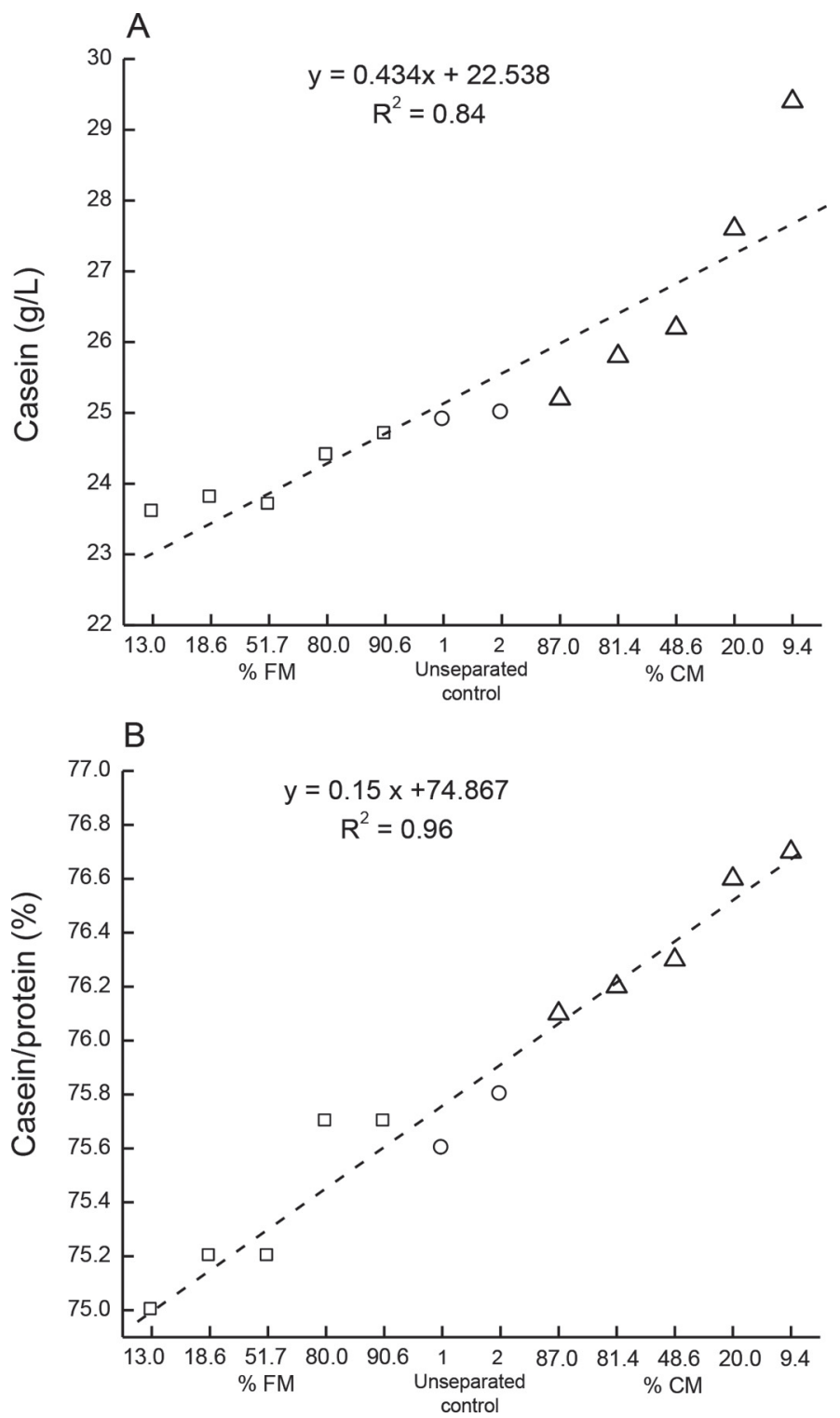

Figure 1. Casein and percent casein of protein according to milk separation cutoff level in A and B tanks and the unseparated controls $(\mathrm{CM}=$ cheese milk, $\Delta$; unseparated, $\mathrm{O} ; \mathrm{FM}=$ fluid milk, $\square)$.

35.6, protein 33.3, casein 25.4, and lactose $50.5 \mathrm{~g} / \mathrm{L}$ ). No differences were found in the moisture of the cheeses at $24 \mathrm{~h}$. Dry matter decreased along storage with a significant drop in the cheese made with no added $\mathrm{Ca}$ (Figure 6). Moreover, a decrease in fat and protein incorporated into the cheese along the storage time was also demonstrated (Figure 7). The recorded optical reflectance of the whey demonstrated that during storage an increase of signal occurred. This means an increase of the TS in the whey, suggesting that fat and protein underwent lipolysis and degradation mainly noted in the cheese made with no added $\mathrm{Ca}$ (Figure 8). 
Table 2. Separation threshold of milk into target A and B tanks and 2 unseparated controls and cheese parameters: protein-to-fat ratio (PTF ratio), curd firmness according to the Optigraph after $60 \mathrm{~min}$ (CF-60), cheese weight at $24 \mathrm{~h}(\mathrm{~W} 24 \mathrm{~h}, \mathrm{~g})$, percent DM in cheese (\% DM), and weight of DM from fresh cheese weight at $24 \mathrm{~h}$ (DM, g)

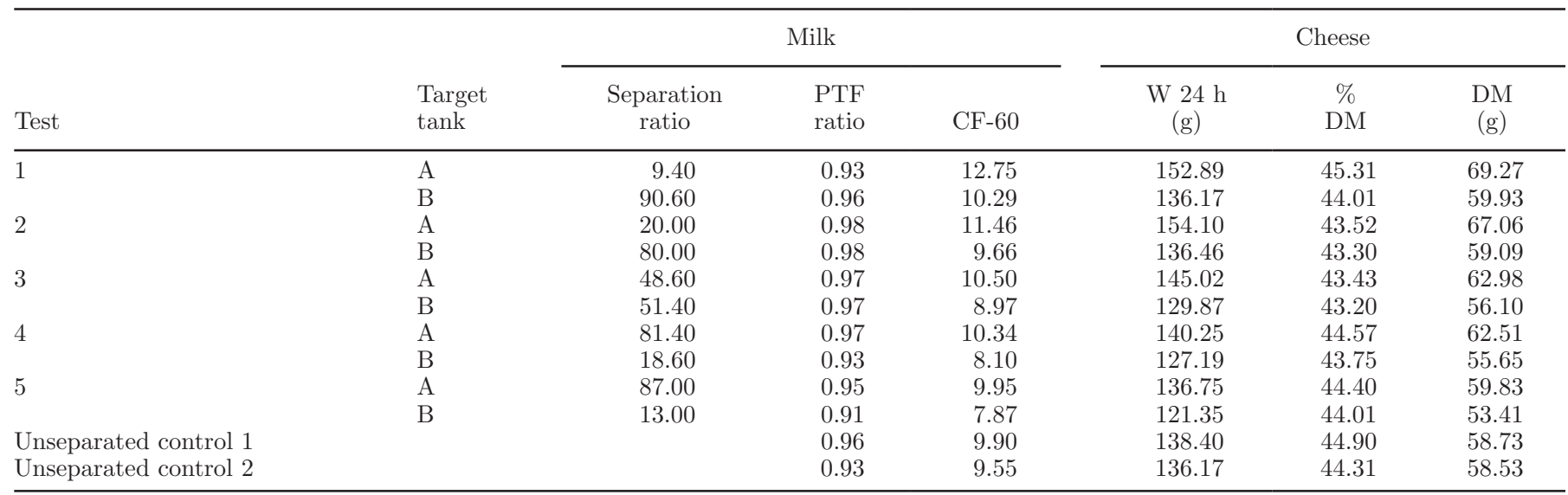

\section{DISCUSSION}

The dairy industry has a long history of adaptation for maximized profitability by selecting the animals' breeds, appropriate management systems, industrial technologies, and equipment for desirable products. Modernization leads to the formation of large dairy farms, most of which produce milk for a variety of products: drinking milk, cultured products, butter, milk desserts, soft and hard cheeses, and so on. Thus, the quality of the milk is not optimized for any of these end products, but is rather an economic compromise. The present study shows that on farm milk separation

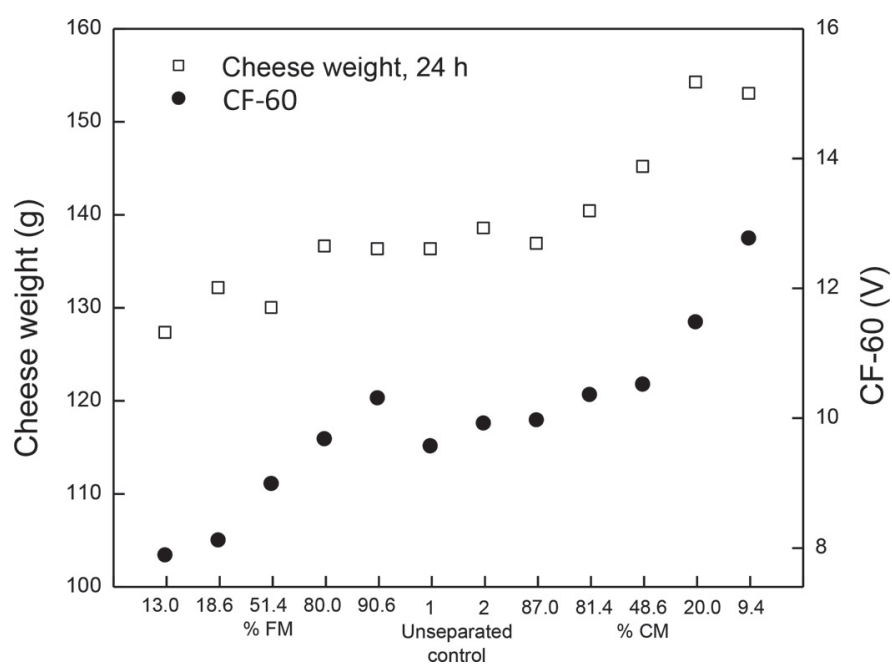

Figure 2. Cheese weight ( $\mathrm{g}$ ) after $24 \mathrm{~h}$ and curd firmness after 60 min (CF-60) value according to milk separation cutoff level into A and $\mathrm{B}$ tanks and the unseparated controls $(\mathrm{CM}=$ cheese milk; $\mathrm{FM}=$ fluid milk). for increased target product yield on a daily basis and with the same animals explicitly increases profitability. This was achieved by using the AfiMilk MCS capability to sort milk on-line according to its measured coagulation properties, Afi-Cf, into bulk milk tanks A or B (Leitner et al., 2011a, 2012, 2013).

In the first part of the study, it was demonstrated that the milk separation process using the AfiMilk MCS capabilities results in 2 distinct extreme different milk compositions in target $\mathrm{A}$ and $\mathrm{B}$ tanks regarding protein as well as casein. Most interesting is the capability of the system to enrich the separated milk in tank A with casein, which further on is incorporated in the cheese

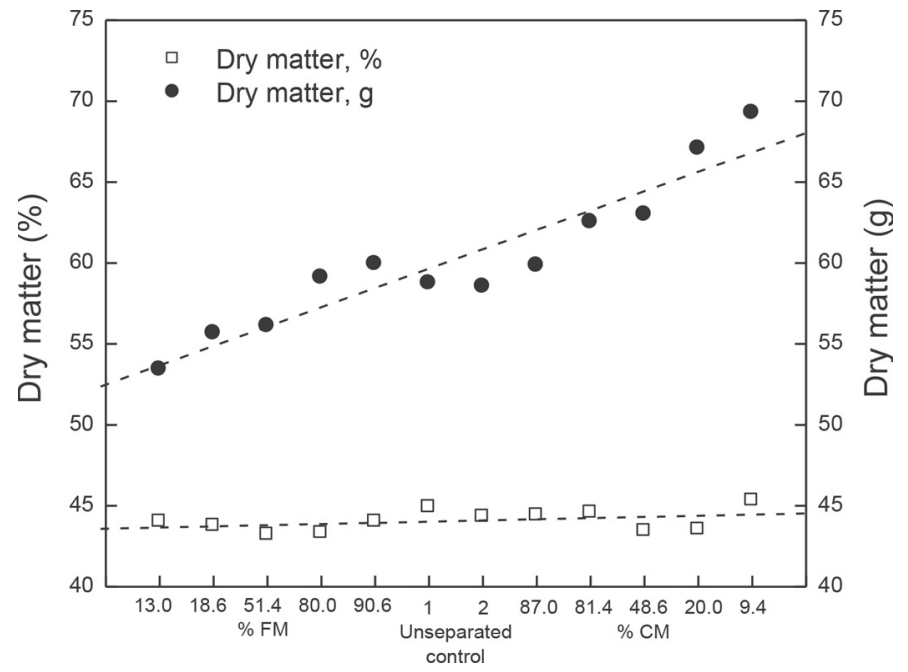

Figure 3. Percent DM in cheese versus DM weight according to milk separation cutoff level into A and B tanks and the unseparated controls $\left(\mathrm{R}^{2}, \% \mathrm{DM}, 0.157 ; \mathrm{R}^{2}\right.$, g of $\left.\mathrm{DM}, 0.880\right)$. $\mathrm{CM}=$ cheese milk; $\mathrm{FM}=$ fluid milk. 

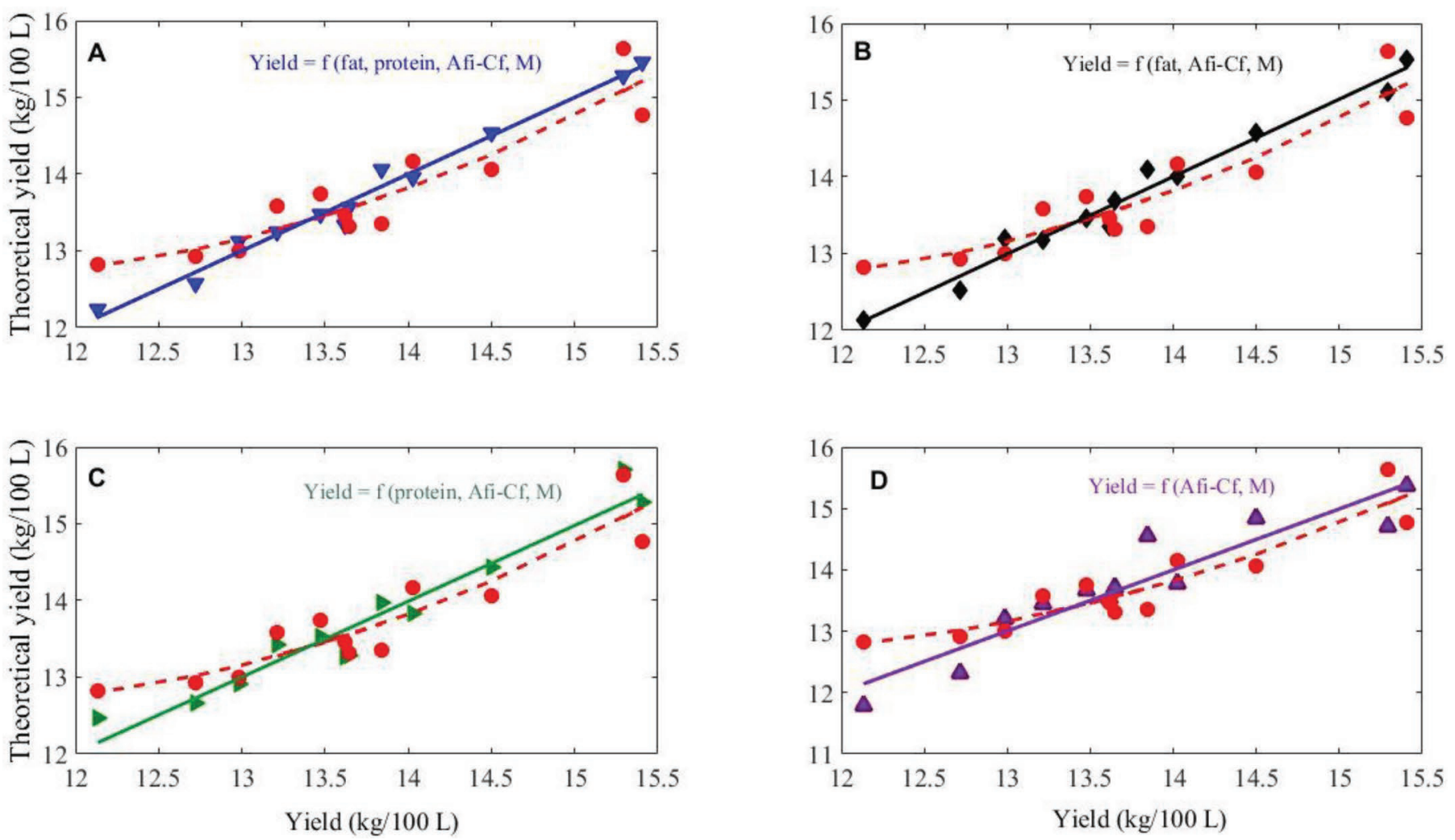

Figure 4. (A) Theoretical van Slyke predicted cheese yield $(\bullet)$ versus actual yield $(\mathbf{\nabla})$ as based on new theoretical predicted yield functions $(\bullet, \boldsymbol{\Delta})$ of milk clotting parameter versus actual yield. A: yield = f (fat, protein, Afi-Cf, M), B: yield =f (fat, Afi-Cf, M), C: yield = f (protein, Afi-Cf, M), D: yield = f (Afi-Cf, M). Afi-Cf = optical measure of curd firmness obtained by the Afilab instrument (Afikim, Israel); M = moisture. Color version available online.

in a higher proportion compared with the increase in protein and casein per se.

By introducing new unknown parameters for calculating the predicted cheese yield, such as the empiric measured Afi-Cf properties (Leitner et al., 2011a, 2012, 2013), it is evident that cheese yield increase is more than increasing just the protein level (the value that is being tested by the dairies) or even casein. The current study indicates that (1) AfiMilk MCS has the potential to use milk more effectively and can lead to a reduction in the number of cows that produce the same amount of milk products or to increase the amount with the same number of cows, and (2) predicting milk curdling is complicated due to the complexity of this process and is more than merely levels of casein and fat.

The study also validates the negative influence of milk storage before processing on its quality (Andrus et al., 2015). Early studies with cow milk showed a reduction of $4 \%$ in curd yield during storage, noted for milk coming from bacteria-free glands (Leitner et al., 2008; Malacarne et al., 2013), and sheep milk negative effect on cheese quality and texture (Rovai et al., 2015a,b).
Moreover, in the studies of Rovai et al. (2015a,b), the influence of storage was higher if the milk was mixed with milk from animals suffering from udder infection. The reductions in cheese quality and texture were probably indicators that casein proteolysis continued during milk storage due to the continuous action of plasmin on the casein micelles (Reimerdes and Herlitz, 1979; Crudden et al., 2005), and if the bulk contained a high proportion of milk from intramammary-infected glands, the reduction in the quality was greater. The lowering of coagulation properties during storage was related to the content of diffusible Ca (Pellegrini et al., 1997; Silanikove et al., 2014) and to a decrease in ionic Ca activity (Leitner et al., 2004a,b; Silanikove et al., 2014). Indeed, in the current study, addition of $\mathrm{CaCl}_{2}$ moderated the reduction in cheese weight and casein and fat loss to the whey during storage.

\section{CONCLUSIONS}

By using the AfiLab MCS system in a commercial dairy farm, it was possible to obtain target milk for a 
Table 3. Separation trails of milk into target A and B tanks (13 A and 14 B) at a 50:50 separation threshold and milk recorded parameters: curd firmness after $60 \mathrm{~min}(\mathrm{CF}-60 ; \mathrm{V})$, fat $(\mathrm{g} / \mathrm{L})$, protein $(\mathrm{g} / \mathrm{L})$, protein-to-fat ratio $(\mathrm{PTF})$, lactose $(\mathrm{g} / \mathrm{L})$, SCC $\left(\times 10^{3}\right)$, cheese weight at $24 \mathrm{~h}$ (cheese $24 \mathrm{~h}, \mathrm{~g})$, percent DM in cheese $(\% \mathrm{DM})$, and total DM in cheese (DM, g), along with average, SEM, $\mathrm{R}^{2}$, and significance level $[P(\mathrm{~F})]$

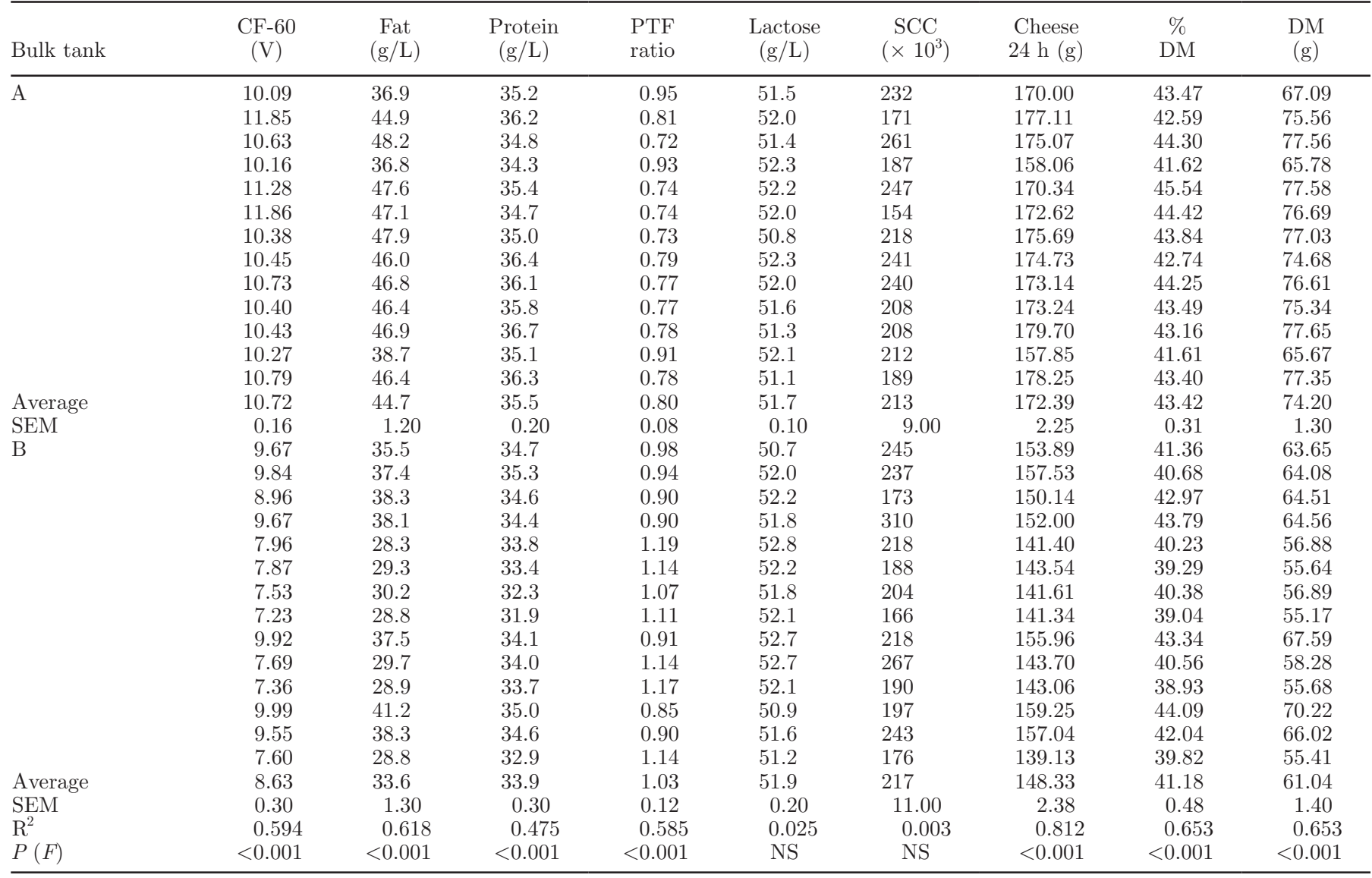

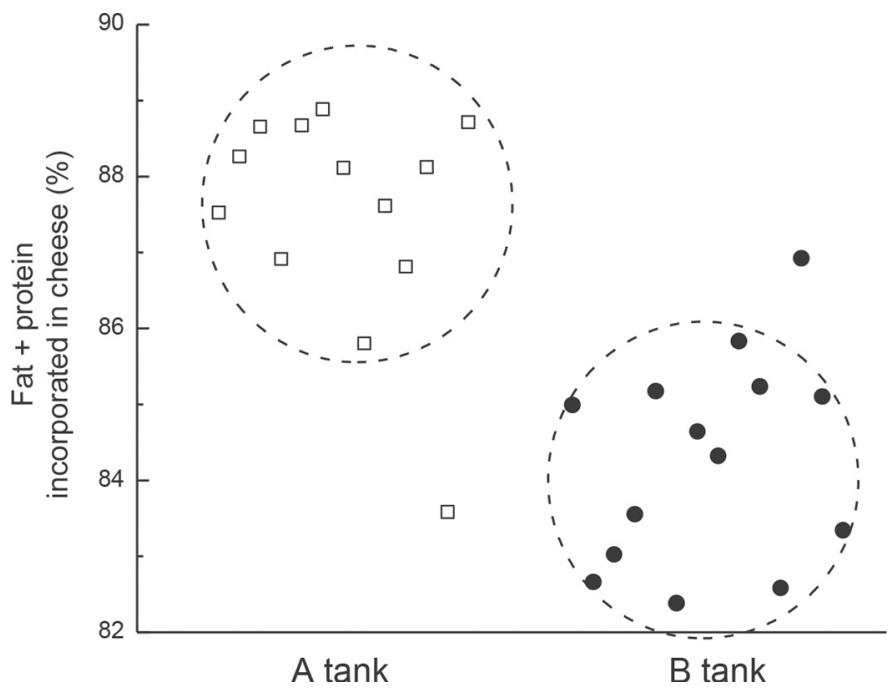

Figure 5. Fat and protein incorporated into the cheese made from milk in target A and B tanks.

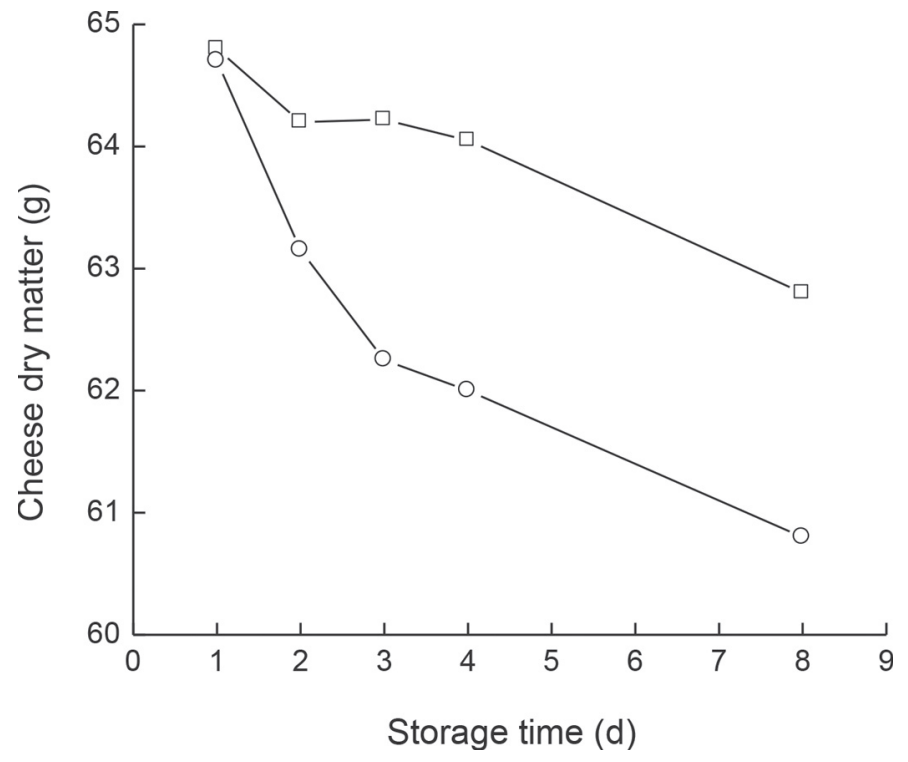

Figure 6. Dry matter in cheese made from stored milk with added $\mathrm{Ca}(\square)$ and without added $\mathrm{Ca}(\bigcirc)$. 


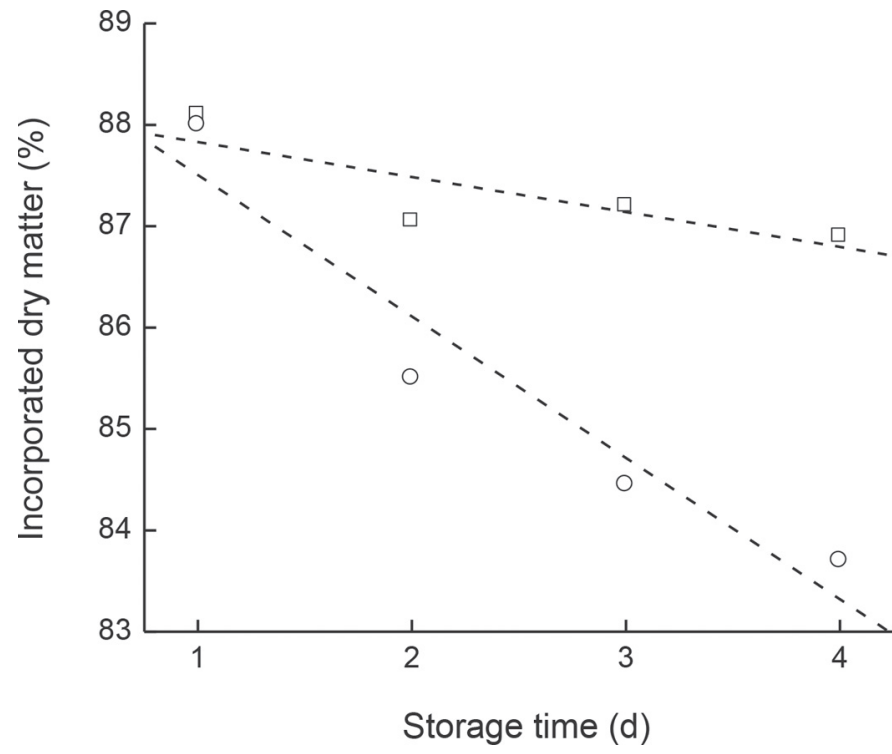

Figure 7. Dry matter incorporated into cheese made from stored milk with added $\mathrm{Ca}(\square)$ and without added $\mathrm{Ca}(\bigcirc)$.

desirable product such as cheese that resulted in an increase of about 10 to $15 \%$ of the cheese vat yield. This yield increase could be of interest for both the dairy and the farmers because it will enable the cheese producer to pay higher prices to the farmers for the separated cheese milk and still maintain higher profitability for the dairy. The study also demonstrates that storage of milk for several days before processing, even when it is obtained with the advantages demonstrated by the Afilab MCS system, is still prone to physico-chemical deterioration processes, which resulted in increased loss of milk constituents to the whey and therefore reduced product yield.

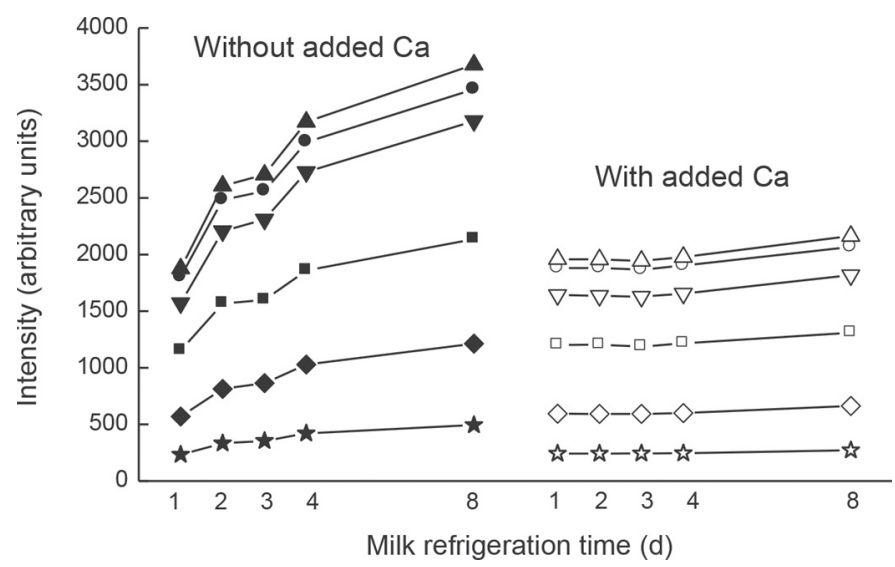

Figure 8. Optical intensity of the whey of cheese made from stored milk with and without added $\mathrm{Ca}$.

\section{REFERENCES}

Aleandri, R., J. C. Schneider, and L. G. Buttazzoni. 1989. Evaluation of milk for cheese production based on milk characteristics and Formagraph measures. J. Dairy Sci. 72:1967-1975.

Andrus, A. D., B. Campbell, K. J. Boor, M. Wiedmann, and N. H. Martin. 2015. Postpasteurization hold temperatures of 4 or $6^{\circ} \mathrm{C}$, but not raw milk holding of 24 or 72 hours, affect bacterial outgrowth in pasteurized fluid milk. J. Dairy Sci. 98:7640-7643.

Auldist, M. J., S. Coats, B. J. Sutherland, J. J. Mayes, G. H. McDowell, and G. L. Rogers. 1996. Effects of somatic cell count and stage of lactation on raw milk composition and the yield and quality of Cheddar cheese. J. Dairy Res. 63:269-280.

Auldist, M. J., and I. B. Hubble. 1998. Effects of mastitis on raw milk and dairy products. Aust. J. Dairy Technol. 53:31-36.

Bangstra, B. A., P. J. Berger, A. E. Freeman, R. E. Deiter, and W S. La Grange. 1988. Economic value of milk components for fluid milk, cheese, butter, and nonfat dry milk and responses to selection. J. Dairy Sci. 71:1789-1798.

Bittante, G., M. Penasa, and A. Cecchinato. 2012. Invited review: Genetics and modeling of milk coagulation properties. J. Dairy Sci. 95:6843-6870.

Boudonck, K. J., M. W. Mitchell, J. Wulff, and J. A. Ryals. 2009. Characterization of the biochemical variability of bovine milk using metabolomics. Metabolomics 5:375-386.

Crudden, A., P. F. Fox, and A. L. Kelly. 2005. Factors affecting the hydrolytic action of plasmin in milk. Int. Dairy J. 15:305-313.

De Marchi, M., G. Bittante, R. Dal Zotto, C. Dalvit, and M. Cassandro. 2008. Effect of Holstein Friesian and Brown Swiss breeds on quality of milk and cheese. J. Dairy Sci. 91:4092-4102.

Emmons, D. B., and H. W. Modler. 2010. Invited review: A commentary on predictive cheese yield formulas. J. Dairy Sci. 93:55175537.

Fox, P. F., and T. M. Cogan. 2004. Factors that affect the quality of cheese. Pages 583-608 in Cheese: Chemistry, Physics and Microbiology. 3rd ed. Vol. 1. P. F. Fox, P. L. H. McSweeney, T. M. Cogan, and P. T. Guinee, ed. Academic Press, London, UK

Guinee, T. P., B. T. O'Kennedy, and P. M. Kelly. 2006. Effect of milk protein standardization using different methods on the composition and yields of Cheddar cheese. J. Dairy Sci. 89:468-482.

Kelly, A. L., G. Leitner, and U. Merin. 2011. Milk quality and udder health-Test methods and standards. Pages 894-901 in Encyclopedia of Dairy Sciences, 2nd ed. J. W. Fuquay, P. F. Fox, and P. L. H. McSweeney, ed. Academic Press.

Kohavi, R. 1995. A study of cross-validation and bootstrap for accuracy estimation and model selection. Proc. 14th International Joint Conference on Artificial Intelligence (IJCAI). Vol. 2, pp. 1137-1143.

Leitner, G., M. Chaffer, A. Shamay, F. Shapiro, U. Merin, E. Ezra, A. Saran, and N. Silanikove. 2004a. Changes in milk composition as affected by subclinical mastitis in sheep. J. Dairy Sci. 87:46-52.

Leitner, G., Y. Lavi, U. Merin, L. Lemberskiy-Kuzin, and G. Katz. 2011a. Online evaluation of milk quality according to coagulation properties for its optimal distribution for industrial applications. J. Dairy Sci. 94:2923-2932.

Leitner, G., Y. Lavon, Z. Matzrafi, O. Benun, D. Bezman, and U. Merin. 2015. Somatic cell counts, chemical composition and coagulation properties of goat and sheep bulk tank milk. Int. Dairy J. http://dx.doi.org/10.1016/j.idairyj.2015.11.004.

Leitner, G., U. Merin, S. Jacoby, D. Bezman, L. Lemberskiy-Kuzin, and G. Katz. 2013. Real-time evaluation of milk quality as reflected by clotting parameters of individual cow's milk during the milking session, between day-to-day and during lactation. Animal $7: 1551-1558$.

Leitner, G., U. Merin, L. Lemberskiy-Kuzin, D. Bezman, and G. Katz. 2012. Real-time visual/near-infrared analysis of milk-clotting parameters for industrial applications. Animal 6:1170-1177.

Leitner, G., U. Merin, and N. Silanikove. 2004b. Changes in milk composition as affected by subclinical mastitis in goats. J. Dairy Sci. $87: 1719-1726$ 
Leitner, G., U. Merin, and N. Silanikove. 2011b. Effects of glandular bacterial infection and stage of lactation on milk quality: Comparison among cows, goats and sheep. Int. Dairy J. 21:279-285.

Leitner, G., N. Silanikove, S. Jacobi, L. Weisblit, S. Bernstein, and U. Merin. 2008. The influence of storage on the farm and in dairy silos on milk quality for cheese production. Int. Dairy J. 18:109-113.

Malacarne, M., A. Summer, P. Franceschi, P. Formaggioni, M. Pecorari, G. Panari, P. Vecchia, S. Sandri, E. Fossa, C. Scotti, and P. Mariani. 2013. Effects of storage conditions on physico-chemical characteristics, salt equilibria, processing properties and microbial development of raw milk. Int. Dairy J. 29:36-41.

Marshall, R. T., ed. 1992. Standard Methods for the Examination of Dairy Products. 16th ed. American Public Health Association, Washington, DC.

Palmquist, D. L., A. D. Beaulieu, and D. M. Barbano. 1993. Feed and animal factors influencing milk fat composition. J. Dairy Sci. $76: 1753-1771$.

Pellegrini, O., F. Remeuf, M. Rivemale, and F. Barillet. 1997. Renneting properties of milk from individual ewes: Influence of genetic and non-genetic variables, and relationship with physicochemical characteristics. J. Dairy Res. 64:355-366.

Reimerdes, E. H., and E. Herlitz. 1979. The formation of $\gamma$-caseins during cooling of raw milk. J. Dairy Res. 46:219-221.

Rovai, M., G. Caja, J. M. Quevedo, C. L. Manuelian, J. Saldo, A. A. K. Salama, P. Torre, I. Arana, X. Such, and G. Leitner. 2015a. Effect of subclinical intramammary infection on milk quality in dairy sheep: II. Matured-pressed cheese (Manchego) produced from milk of uninfected and infected glands and from their blends. Small Rumin. Res. 126:59-67.
Rovai, M., N. Rusek, C. Gerardo, J. Saldo, and G. Leitner. 2015b. Effect of subclinical intramammary infection on milk quality in dairy sheep: I. Fresh-soft cheese produced from milk of uninfected and infected glands and from their blends. Small Rumin. Res. 125:127-136

Shao, J. 1993. Linear model selection by cross-validation. J. Am. Stat. Assoc. 88:486-494

Silanikove, N., U. Merin, F. Shapiro, and G. Leitner. 2014. Subclinical mastitis in goats is associated with upregulation of nitric oxidederived oxidative stress that causes reduction of milk antioxidative properties and impairment of its quality. J. Dairy Sci. 97:34493455 .

Tufarelli, V., M. Dario, and V. Laudadio. 2009. Milk yield and composition of lactating Comisana ewes fed total mixed rations containing nitrogen sources with different ruminal degradability. Livest. Sci. 122:349-353.

van Slyke, L. L. 1907. Methods of commercial testing and scoring of milk and cream. Pages 182-192, chapter XIV, in Modern Methods of Testing Milk and Milk Products. Orange Judd Company, Keagan Paul, Trench Trubner \& Co. Ltd., New York, NY.

van Slyke, L. L., and W. V. Price. 1941. Conditions affecting proportions of constituents in milk. Pages 16-29, chapter II, in Cheese. Orange Judd Company, Keagan Paul, Trench Trubner \& Co. Ltd., New York, NY.

Wedholm, A., L. B. Larsen, H. Lindmark-Mansson, A. H. Karlsson, and A. Andren. 2006. Effect of protein composition on the cheesemaking properties of milk from individual dairy cows. J. Dairy Sci. 89:3296-3305. 